Article

\title{
Erosive Response of Non-Glaciated Pyrenean Headwater Catchments to the Last Major Climate Transition and Establishing Interglacial Conditions
}

\author{
Kurt Martin Stange ${ }^{1, *}$, Ivar Midtkandal ${ }^{2} \mathbb{E}$, Johan Petter Nystuen ${ }^{2}$, Andrew Murray ${ }^{3}$, \\ Reza Sohbati $^{4}$, Warren Thompson ${ }^{3}$, Cornelia Spiegel ${ }^{1}$ (D) and Hans-Joachim Kuss ${ }^{1}$ \\ 1 Faculty of Geosciences, University of Bremen, 28359 Bremen, Germany; \\ cornelia.spiegel@uni-bremen.de (C.S.); kuss@uni-bremen.de (H.-J.K.) \\ 2 Department of Geosciences, University of Oslo, 0371 Oslo, Norway; ivar.midtkandal@geo.uio.no (I.M.); \\ nystuen@geo.uio.no (J.P.N.) \\ 3 Nordic Laboratory for Luminescence Dating, Department of Geoscience, Aarhus University, 8000 Aarhus, \\ Denmark; andrew.murray@geo.au.dk (A.M.); wathom@dtu.dk (W.T.) \\ 4 Center for Nuclear Technologies, Technical University of Denmark, DK 4000 Roskilde, Denmark; \\ resih@dtu.dk \\ * Correspondence: kurtmartinstange@gmail.com; Tel.: +49-1625260510
}

Received: 5 March 2019; Accepted: 22 April 2019; Published: 7 May 2019

\begin{abstract}
Non-glaciated mountain headwater catchments feature high-resolution geomorphic archives, which provide important insight into erosive processes and sediment dynamics in mountain ranges. As such the Valle de la Fueva catchments in the southern Pyrenees present high-lying talus remnants, extensive denudation surfaces (pediments), deeply incised tributary ravines, and low-lying fluvial-cut terraces. Based on geomorphic analyses and absolute dating using terrestrial cosmogenic nuclides and optically stimulated luminescence, a (late stage) catchment erosion model for the Valle de la Fueva was elaborated and indicates successive development stages of (i) lasting pedimentation under cold-climate conditions during Marine Isotope Stages 4-2, (ii) rapid fluvial dissection, sediment remobilization and downcutting of ravines in response to the last major climate transition and establishing interglacial conditions, and (iii) late stage fluvial incision after 3-4 ka due to regionally increased flood magnitudes, and/or intensification of agriculture and forest management. Valle de la Fueva headwater catchment analysis indicated that the styles and magnitudes of basin surface processes were directly correlated with the amplitude and nature of paleoclimatic changes, modified by the interplay of environmental parameters. In contrast to large-scale fluvial systems, mountain headwater catchments seemed to be less afflicted with temporal and spatial averaging biases. They are thus useful targets for investigating direct climate change effects, surface process coupling, and non-linear response mechanisms in Quaternary fluvial systems.
\end{abstract}

Keywords: catchment erosion; Holocene; cosmogenic nuclide dating; OSL; Pyrenees; geomorphology; basin analysis

\section{Introduction}

A great deal of research has been carried out on the long-term evolution of drainage networks and for understanding the coupling and feedback mechanisms between climate, tectonics, fluvial system dynamics, and surface processes in general; e.g., [1-10]. It has been shown that fluvial systems tend to produce extensive terrace staircases in response to eccentricity-driven Quaternary climate cycles and related discharge fluctuations, superimposed on progressive valley downcutting in response to long-term steady uplift; e.g., [8,11]. And yet, in detail relationships and feedback mechanisms may 
be non-linear and much more complex; e.g., $[4,12,13]$. Research on large-scale fluvial systems thus entails some issues that need to be resolved. For instance, long-term fluvial incision rates derived from the vertical spacing of terrace staircase systems are potentially misleading as to the actual magnitudes of paleo-surface processes. This is because erosion rates that are calculated from vertical (i.e., two-dimensional) incision scarps between adjacent terrace features are potentially afflicted with spatial- and time-averaging biases-the latter of which increases with the age of terraces. This includes potential time lags, for instance, between glacial headwater dynamics and downstream fluvial response. The Cinca River in the southern Pyrenees is a typical example of an extensively glaciated mountain catchment with prominent alluvial terraces staircases along its foreland reaches. Large-scale drainage basins like the Cinca are often affected by repeated sediment reworking and allochthonous discharge fluctuations, which may complicate the interpretation and reduce precision of absolute terrace dating. Hence, the direct forcing and precise timing (i.e., onset, offset, and actual duration) of erosion and aggradation phases in large-scale drainage systems is difficult to assess and reliable quantitative data is needed.

To date, relatively little attention has been paid to the morphogenetic evolution of non-glaciated headwater catchments in Mediterranean mountain ranges and their response mechanisms to external forcing such as major climate transitions; e.g., [13-17]. This is surprising because non-glaciated headwater catchments like the Valle de la Fueva feature is well preserved and high-resolution geomorphic archives that reflect the (in situ) impact of local environmental and climatic changes on drainage basin development [18]. It can only be explained by the fact that during the last glacial cycle most of the Mediterranean mountain catchments were extensively glaciated; e.g., Cinca River [19,20].

And yet, headwater drainage basins are typical topographic features of many mountain ranges whose sedimentary archives contain valuable information on the dynamics and magnitudes of erosion-sedimentation processes in a mountain chain [21,22]. Syn- and postdepositional structures in sediment outcrops like stratigraphy, soils, clast imbrication, refilled ice-wedges, and deformations, may reveal the nature of erosion-sedimentation processes and disclose important environmental changes related to, for instance, climate fluctuations and tectonic activity; e.g., [23-25]. On a larger scale, mapping of basin topography and geomorphic features such as talus remnants, erosion surfaces, and river terraces are geomorphic markers, which enable correlation of individual morphogenetic complexes and drainage basin development stages [18]. Methodological advances in digital elevation models and in absolute dating techniques like terrestrial cosmogenic nuclides (TCN), e.g., [26-28], and optically stimulated luminescence (OSL), e.g., [29-31], now allow for high-resolution geomorphic analyses and for establishing precise exposure and burial history of rocks and sediments in a wide range of settings. In combination, absolute dating, digital terrain analysis, mapping, and field observations enable the quantification of surface processes and time-dependent erosion models, the latter having proved useful for assessing the magnitudes of erosion-sedimentation processes and their external, climatic, and tectonic forcing $[8,18,32-34]$.

With the goal of determining the direct drivers, feedback mechanisms, and timing in fluvial system development, non-glaciated $10-100 \mathrm{~km}^{2}$ headwater catchments of the Cinca River (Figure 1) were investigated as to the temporal and spatial scales and the external/internal parameters of successive catchment erosion phases in response to climate change during the late stages of Marine Isotope Stage (MIS) 2 and the establishing Holocene Interglacial. In extension to Stange et al. [18], this paper presents catchment erosion rates, volumetric measurements and sediment budgets, as well as new TCN- and OSL-derived chronological data for the most recent fluvial erosion phase in the Valle de la Fueva headwater catchments in the southern central Pyrenees (Figure 1). 


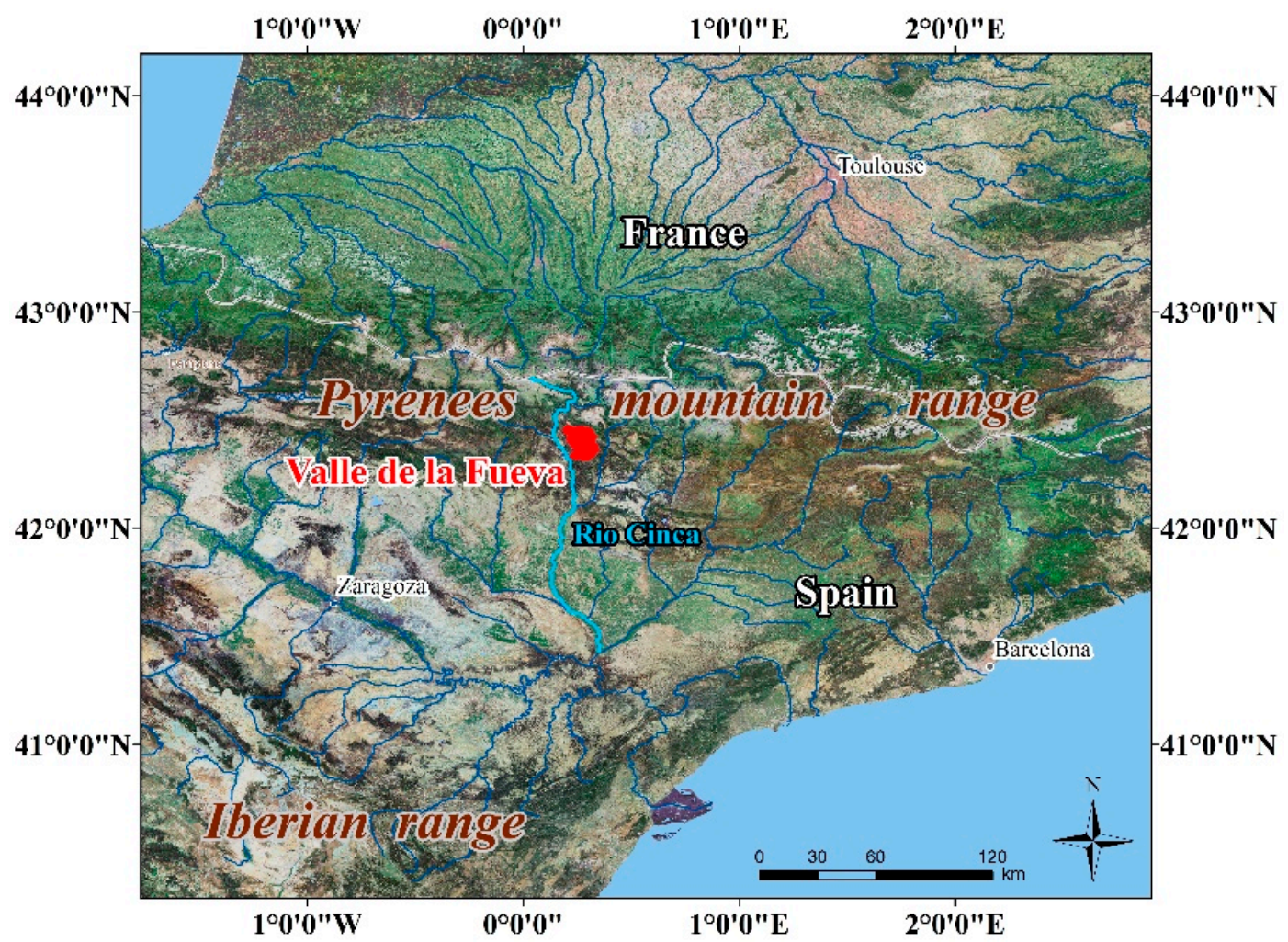

Figure 1. Imagery of the Pyrenees region showing the location of the Valle de la Fueva drainage basin and the course of its main river Río Cinca.

\section{Settings}

Covering an area of c. $190 \mathrm{~km}^{2}$, the Valle de la Fueva is a highly erodible drainage basin that is characterized by intensely deformed shallow and deep marine strata (e.g., marl, shale, slate, and sandstone), conglomerates, and synorogenic debris [18,35-38]. The basin is confined within steep structural valley margins composed of erosion resistant limestone and sandstone ridges that practically encircle the depression [18,39]. The Valle de la Fueva consists of two major catchments: The Valle de la Fueva Alta (c. $100 \mathrm{~km}^{2}$ ) and the Valle de la Fueva Baja $\left(\right.$ c. $90 \mathrm{~km}^{2}$ ), which are separated by a degraded central drainage divide (Figure 2). Along its crest line, marked wind gaps render possible a previous drainage connection between the Fueva Alta and Fueva Baja catchments [18]. Considering internal tributary drainage divides, the Fueva Alta and Fueva Baja drainage basins can be further divided into five to eight subcatchments named after their principal rivers (Figure 2). Creeks and tributary rivers drain the Valle de la Fueva catchments to the southwest into the Embalse de Mediano (c. $500 \mathrm{~m}$ a.s.l.), one of the largest reservoir lakes in northern Spain that retains and regulates the discharge of the Cinca River.

Río Cinca is one of the major southern Pyrenees streams and constitutes the drainage base level of the Valle de la Fueva. In proximity to the Valle de la Fueva headwater catchments, the Cinca valley presents extensive aggradational terraces and prominent staircase cross-sections dated as middle to late Quaternary [19]. On the eastern flank of the Cinca valley, La Fueva tributary rivers cut prominent outlet canyons into the Mediano anticline that are relevant to the base level history of the Valle de la Fueva [18]. Longitudinal stream profile analyses showed that Fueva Alta tributaries generally have concave-up profiles, which, at present, are base level adjusted to the main river Cinca, at least along their lower-middle reaches. In the Valle de la Fueva Baja, however, prominent gradient changes (or stream profile knickpoints) along the outlet canyon indicate that Fueva Baja stream profiles are in disequilibrium and not (yet) base level adjusted to the Cinca main river profile [18]. 


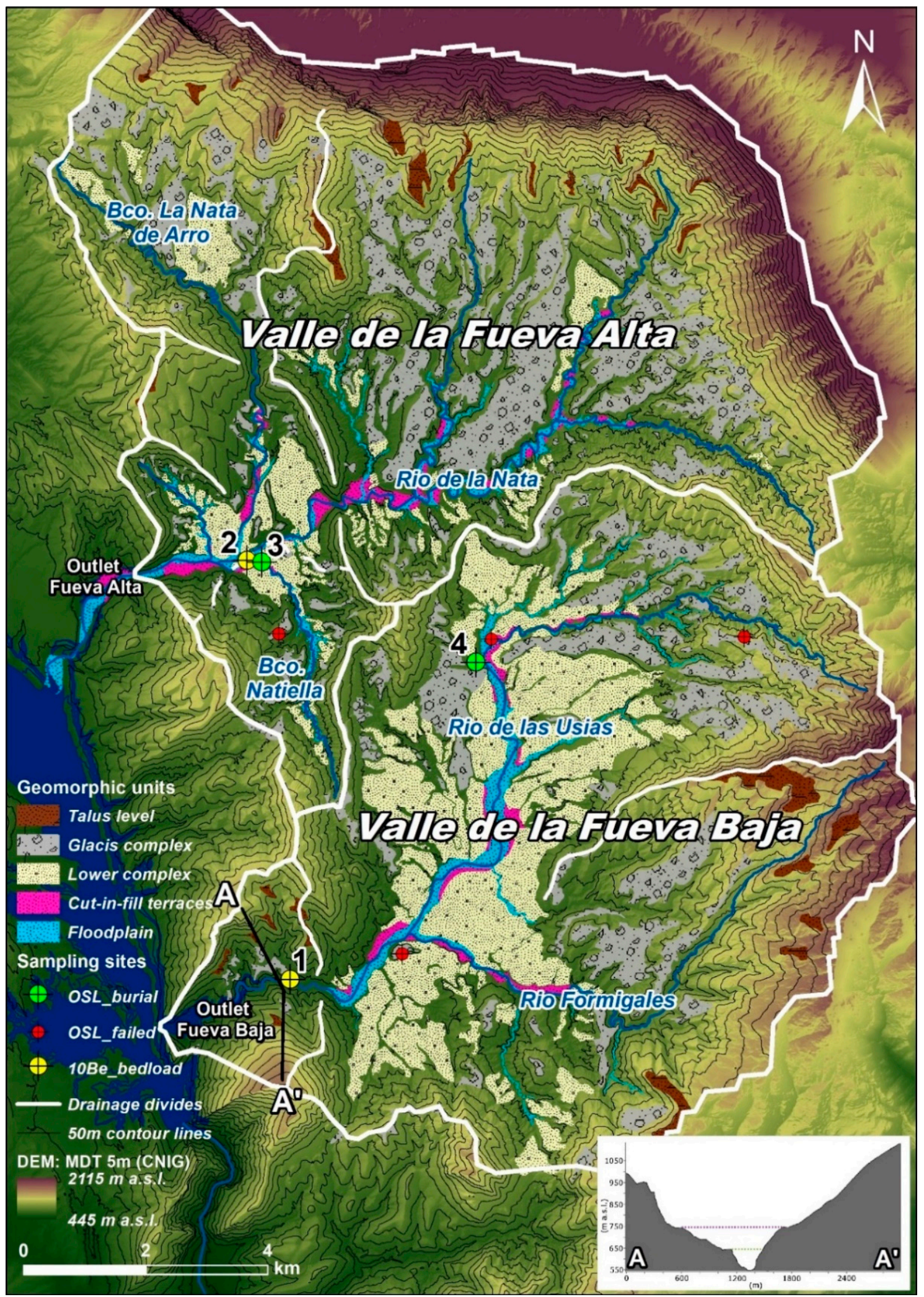

Figure 2. Geomorphological map of the study area showing the morphogenetic units of the Valle de la Fueva, locations of TCN/OSL sampling sites, and the main tributaries and drainage divides. Inset: Topographic cross-section $\left(\mathrm{A}-\mathrm{A}^{\prime}\right)$ of the Fueva Baja outlet canyon. 
Across the Valle de la Fueva, remnants of high-lying talus plateaus and lateral talus slopes along the basin margins denote the top basin fill surface before the onset of intense late-stage basin erosion and fluvial dissection. To date, no age controls exist for talus formation in La Fueva, but talus plateaus have actively been levelled during MIS 4-2 cold climate conditions [18]. The most striking geomorphic features in the Valle de la Fueva are extensive residual erosion (denudation) surfaces. They are commonly described as pediments or 'mantled' pediments (glacis), the latter having meter-thick cover sediments preserved [40]. The (mantled) pediments are characterized by shallow sloping surfaces of c. $0.5-4 \%$ and $2-8 \mathrm{~m}$ thick colluvial cover sediments over smoothed erosive bedrock interfaces of the underlying marls and shales. Surface geometries and ${ }^{10} \mathrm{Be}$ exposure dating confirmed that the most extensive pediments are correlated and that associated pediment-glacis complexes developed under cold climate conditions of the last glacial cycle MIS 4-2 [18]. This includes that pedimentation was supported by repeated snow-pack melting which repeatedly destabilized the pediment cover sediments, and by periglacial processes which supplied the debris from the surrounding highs towards the denudation plains. Around the Last Glacial Maximum (LGM), pediments became inactive and were abandoned as actively eroding surfaces, the latest after c. $18 \mathrm{ka}$ [18]. During the Holocene climate transition intense fluvial dissection created a network of rills and gullies, which successively widened and deepened to prominent tributary ravines (barrancos). The formation of barrancos in the Valle de la Fueva is clearly climate triggered, but it seems to be out-of-phase with regard to the terrace chronology and incision history of the main river Cinca (e.g., Quaternary terrace ('Qt') 9, c. 10 m a.f., $11 \pm 1$ ka; [19]).

In addition, Valle de la Fueva tributary barrancos feature low-lying fluvial-cut terraces situated at 2-4 $\mathrm{m}$ above the present floodplain ( $\mathrm{m}$ a.f.). Terrace geometries and thicknesses are very heterogeneous and complicate terrace correlations across the Valle de la Fueva. Overall, lateral terrace outcrops are characterized by cover fines of variable thickness over mixed alluvial and colluvial material (i.e., cobbles, gravel, debris flow deposits) underlain by fluvial-cut bedrock of marl, shale, and slate [18]. The heterogeneity of the terrace bulk sediments reflects that these terraces are not purely alluvial in nature. Valley cross-sections and terrace feature geometries indicate that barranco formation in the Valle the la Fueva involved at least one major and one minor late-stage incision/erosion phases. The 2-4 m vertical scarps of low-lying fluvial-cut terraces situated within the narrow tributary valleys thus naturally mark the latest incision event in the Valle de la Fueva, which can be observed across the entire Valle de la Fueva drainage basin.

\section{Methods}

\subsection{Digital Terrain Analysis}

For elaborating a time-dependent catchment erosion model and determining the eroded sediment volumes in the Valle de la Fueva, field observations and absolute age constraints were integrated with established morpho-stratigraphic classifications [18]. Using built-in ESRI ArcGIS toolboxes, feature polygons were produced and classified, and interpolated with a high-resolution digital elevation model (i.e., Modelo Digital del Terreno (MDT) 5 m, Instituto Geográfico Nacional de España) using the 3D-Analyst functional surface tool. In order to reconstruct the paleo-topographic catchment development, fluvial-cut terraces and barranco shoulders that mark the brim of extensive pedimentation surfaces were taken as feature elevation reference points for extrapolating paleo-basin surfaces using ArcGIS 3D-Analyst and raster interpolation. From each reference paleo-surface (e.g., Figure 3) an individual raster elevation model was produced with 3D-Analyst TopoToRaster. In a last step, 3D-Analyst cut-fill operations were carried out for determining NetGain and NetLoss volumes between the different raster surfaces and the missing (i.e., eroded) sediment volumes were calculated. Being based only on distinctly preserved topographic features, the resulting excavated volumes should be regarded as minimum estimates. 


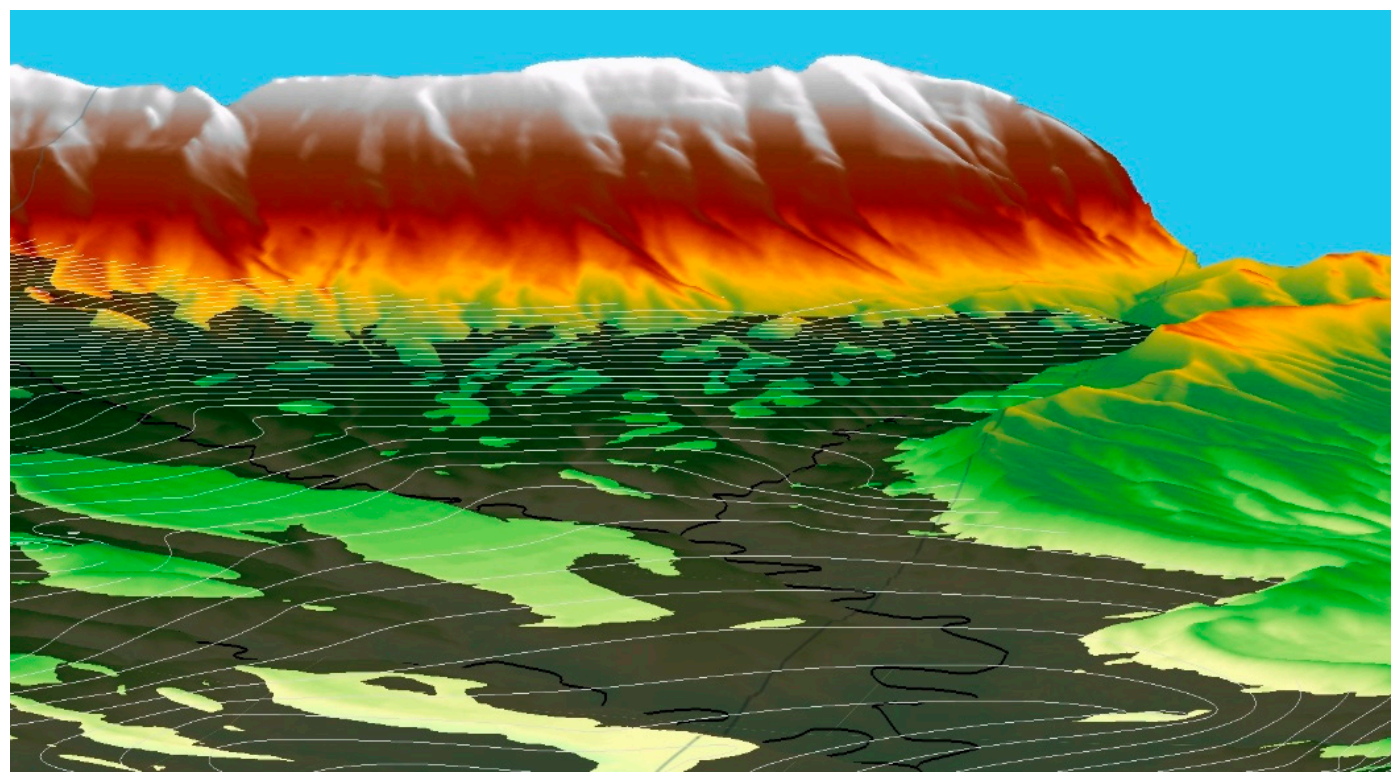

Figure 3. ESRI ArcScene snapshot showing pediment reference surfaces (green-shaded, left) and domains characterized by net volume loss (black-shaded) with regard to the reconstructed late MIS 2 reference surface for the Valle de la Fueva Alta (cf. contour lines).

\section{2. ${ }^{10}$ Be Catchment Erosion Rates}

In continuation of previously published TCN exposure dating on the main geomorphic talus and pediment units in the Valle de la Fueva [18], additional sediment samples were collected from catchment outlets for TCN-based catchment-scale erosion rates, and from low-lying terraces for establishing additional OSL age constraints for the latest erosion phase. Typical applications of in situ produced terrestrial cosmogenic nuclide (TCN) dating are exposure and burial histories of rocks and sediments, e.g., [27,41,42]. Recent advances in cosmogenic nuclide dating brought forth new applications such as TCN-derived catchment-wide erosion rates $[43,44]$ : Mountain landscapes are progressively eroded and levelled towards a steady state where relief energy is minimal [45]. In this process, rocks are eroded, new material is brought to the surface, and sediment is produced and transferred to adjacent topographic lows. Once material reaches (near) the surface, the permanent flux of cosmic rays triggers nuclear reactions [27] and the built-up of radioactive (unstable) cosmogenic isotopes (e.g., ${ }^{10}$ Beryllium) in mineral grains like quartz. The concentration of TCN inventories in surface sediments is a function of time and a number of site specific parameters such as topographic shielding, spatial scaling, production rates, erosion, and radio-nuclide half-life [41].

Sediment samples were collected at suitable catchment outlets representing an aggregate of about $1 \mathrm{~kg}$ of in situ alluvial sand and gravel with variable but sufficient quartz proportions. Cosmogenic catchment-wide (erosion) rates are based on the principle that the accumulation of cosmogenic nuclides is proportional to the erosion rate [27] and that bedload sediment was thoroughly mixed by hillslope and fluvial processes. Hence, mixed bedload samples are thought to integrate the various TCN inventories from the entire (upstream) drainage basin area $[46,47]$ and enable the calculation of spatially averaged (upstream) catchment erosion rates [27,44].

For testing this TCN application in the Valle de la Fueva and comparing this headwater catchment with other drainage basin settings, two aggregate sediment samples were analyzed for the ${ }^{10} \mathrm{Be}$ analysis. These samples were collected from the present-day riverbed at the outlets of the Valle de la Fueva Baja catchment and the Fueva Alta tributary subcatchment of Rio Natiella (Figure 4). The latter site was chosen because quartz-rich sediments are scarce across the Valle de la Fueva Alta. Only the Natiella subcatchment features homogeneous quartz-bearing lithologies in the upstream catchment, providing sufficient quartz-bearing bedload material for the ${ }^{10} \mathrm{Be}$ analysis at its outlet. TCN sample processing was 
done following state-of-the-art laboratory procedures of the CosmoLab at Bremen University. Beryllium was extracted and isolated using single-step column chromatography developed by Binnie et al. [48]. ${ }^{10} \mathrm{Be} /{ }^{9} \mathrm{Be}$ ratios were measured at CologneAMS (AMS standards used: KN01-6-2 and KN01-5-3). Analytical uncertainties and systematic errors related to production rates and ${ }^{10} \mathrm{Be}$ radionuclide half-life of $1.387 \pm 0.012 \mathrm{Myr}[49,50]$, are factored into the reported erosion rate uncertainties. Applying the scaling scheme of Stone [51], modified from Lal [43], cosmogenic erosion rates were calculated with CRONUS-Earth online calculators 2.3 developed by Balco et al. [52] using ${ }^{10} \mathrm{Be}$ standardization 07KNSTD. The resulting catchment wide erosion rates were scaled to the mean altitude of the specific upstream drainage basin, which was determined using ArcGIS raster statistics for 3D digital elevation models (DEM, cf. Table 1). Mean latitude refers to the 2D geometric centroid of the catchment polygons. Topographic shielding at these synthetic catchments mean elevation reference points (Table 1) was measured as negligible on site and set at value one (i.e., no shielding). Snowpack shielding was not calculated owing to a lack of constraints and because of the rare and short duration of nival shielding compared to the overall timescales involved (i.e., post-glacial period, 10-20 kyr).

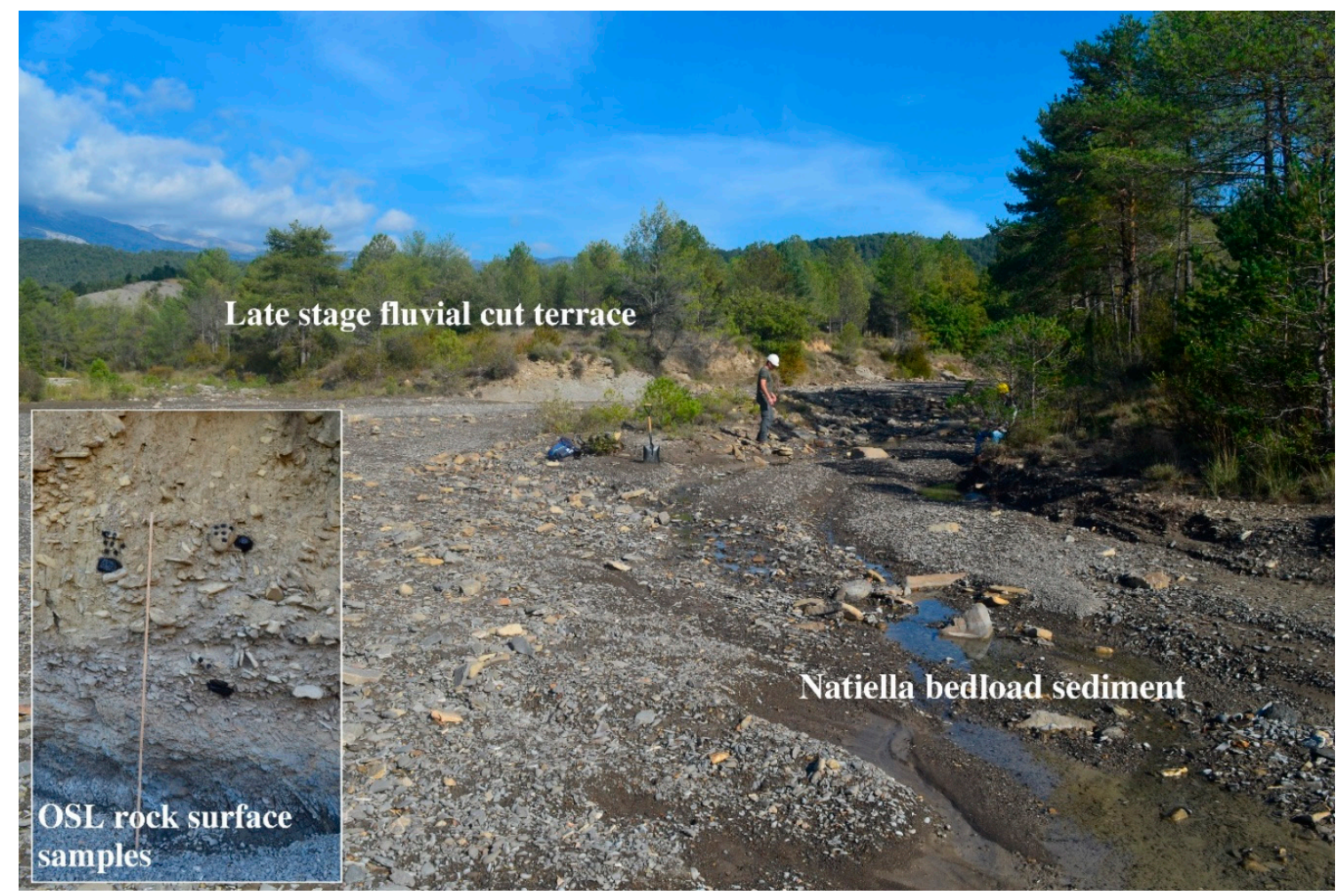

Figure 4. Outlet of the Natiella catchment and ${ }^{10}$ Be bedload sampling site 2. Inset: OSL sampling of buried cobbles in a low-lying fluvial-cut terrace at site 3.

Table 1. Bedload sampling sites (Figure 4) and reference locations used for ${ }^{10} \mathrm{Be}$ catchment wide erosion rates that were calculated with CRONUS-Earth online calculator 2.3. Scaling scheme applied: Stone [51], modified from Lal [43].

\begin{tabular}{cccccc}
\hline Sample ID & Sampling Site & Catchment & $\begin{array}{c}\text { Mean Latitude } \\
\text { [dec. deg.] }\end{array}$ & $\begin{array}{c}\text { Mean Longitude } \\
\text { [dec. deg.] }\end{array}$ & $\begin{array}{c}\text { Mean Elevation } \\
\text { [m a.s.l.] }\end{array}$ \\
\hline S-45 & $2408 / 2409$ & Fueva Baja & 42.36124 & 0.27722 & 805 \\
\hline S-48 & 3303 & Natiella & 42.38569 & 0.23082 & 714 \\
\hline
\end{tabular}




\subsection{OSL Rock Surface Dating}

For dating the youngest morpho-sedimentary units in the Valle de la Fueva, TCN exposure/burial dating was not applicable due to unconstrained erosion/burial of terrace surfaces and TCN burial dating age limits, e.g., [27,53]. Moreover, conventional OSL sediment dating was hampered by insufficient quantities of quartz/feldspar in the matrix materials, and so OSL rock surface dating, e.g., [31,54], was applied to cobble-sized sandstone, feldspathic and lithic arenite clasts from terrace sediment outcrops. Six fluvial-cut terraces (codes 3301-06) were sampled in total. At each site up to seven clasts ( $\sim 15 \mathrm{~cm}$ across) were identified in the section, and the exposed surfaces were spray-painted black to enable the identification of the buried surfaces in the laboratory (cf. Figure 4). The clasts were then excavated and immediately placed in opaque plastic bags to minimize the light exposure. An additional sediment sample $(\sim 300 \mathrm{~g})$ was collected from around each of the clasts for radionuclide analysis.

In the laboratory the clasts were washed and $20 \mathrm{~mm}$ diameter cores were drilled from the previously buried surfaces using a diamond-tipped water-cooled coring drill. Each core was then cut into $\sim 1.2 \mathrm{~mm}$ thick slices using a Buehler IsoMet low-speed saw equipped with a $0.3 \mathrm{~mm}$ thick water-cooled diamond-tipped blade, giving a net slice spacing of $\sim 1.5 \mathrm{~mm}$. These slices were then gently broken into small chips, and placed loose in $10 \mathrm{~mm}$ diameter stainless steel cups for luminescence measurement. For those clasts identified as suitable for further measurement, an additional $\sim 100 \mathrm{~g}$ portion of each was pulverized, mixed with wax and cast in a cup-shaped mold for radionuclide analysis by high resolution gamma spectrometry $[55,56]$. The sediment samples were dried, crushed, and ignited at $400{ }^{\circ} \mathrm{C}$ before casting in a similar manner. The luminescence signals from the rock fragments were measured using a Risø TL/OSL reader model 15 or 20, each equipped with a calibrated ${ }^{90} \mathrm{Sr} /{ }^{90} \mathrm{Y}$ beta source delivering a dose rate to quartz of $\sim 0.1 \mathrm{~Gy} / \mathrm{s}$ [57]. Radioactivity measurements were made using one of several high resolution gamma spectrometers calibrated against IAEA standards [56]. Radionuclide concentrations were converted into dry dose rates using the conversion factors given in [58] and the effects of water in the surrounding sediment were accounted for based on the factors given in [59]. The water content in the cobbles was assumed to be negligible. The contribution to dose rate from cosmic rays is based on [60].

Preliminary measurement of OSL using blue stimulation indicated that no samples gave a useful signal, and so all further measurements used infrared (IR) stimulation. The resulting signals are presumed to derive from predominantly K-rich feldspars, although no mineral separation was undertaken to test this (widely accepted) hypothesis. Initial measurements of IR stimulated luminescence (IRSL) suggested that only the signal stimulated at or close to room temperature was likely to have been reset in nature, and so the SAR measurement sequence [61,62] given in Table 2 was adopted. Using this sequence, the ratio $\mathrm{L}_{0} / \mathrm{T}_{0}$ was measured for each slice from each core.

Table 2. OSL analysis measurement protocol.

\begin{tabular}{ccc}
\hline Step & Treatment & Measurement \\
\hline 1 & Give regenerative dose, $\mathrm{D}_{\mathrm{i}}$ & - \\
\hline 2 & Preheat to $250{ }^{\circ} \mathrm{C}$ for $100 \mathrm{~s}$ & - \\
\hline 3 & Stimulate at $50{ }^{\circ} \mathrm{C}$ with IR for $200 \mathrm{~s}$ & $\mathrm{~L}_{\mathrm{i}}$ \\
\hline 4 & Give fixed test dose, $\mathrm{D}_{\mathrm{T}}$ & - \\
\hline 5 & Preheat to $250{ }^{\circ} \mathrm{C}$ for $100 \mathrm{~s}$ & $\mathrm{~T}_{\mathrm{i}}$ \\
\hline 6 & Stimulate at $50{ }^{\circ} \mathrm{C}$ with IR for $200 \mathrm{~s}$ & - \\
\hline 7 & Stimulate at $290{ }^{\circ} \mathrm{C}$ for $200 \mathrm{~s}$ & -
\end{tabular}

Note: When i $=0$ (natural measurement), Di = 0 Gy. Step 7 is to ensure the signal is reset to zero before beginning a new cycle of measurement. 


\section{Results}

\subsection{OSL Rock Surface Dating}

In order to derive a luminescence age for a cobble: (i) We should be able to drill and then slice it, (ii) its constituent quartz and/or feldspar minerals should be sensitive (i.e., give detectable luminescence signal), and (iii) it's surface should have been well-bleached prior to burial (i.e., should have a S-shaped profile). We started off by targeting three cobbles per site and even if only one out of three passed the first two criteria above, we went on to measure more cobbles from the same site. Unfortunately, many of the cobbles were very brittle and broke into small unusable fragments during coring or slicing, and so we had to dismiss them. Also, some of the cobbles did not yield any measurable IRSL signal. In total, only 23 out of 43 cobbles could be cored and sliced and gave a detectable IRSL signal. Out of 23, 20 cobbles had seen no or very limited light prior to burial. Only three cobbles had seen sufficient light to reset their latent luminescence signal before burial, and these were the ones that we could date (Figure 5). Two of these clasts were from the youngest terrace (i.e., samples 3304-2 and 3304-6, location 3, Figure 2) and one from an older terrace (i.e., 3305-05, location 4, Figure 2). For samples 3304-2 and 3304-6 additional cores were taken from the other buried surfaces to investigate: (i) Whether all buried surfaces had been reset by daylight exposure before burial and (ii) whether the buried surfaces of a clast were all covered from daylight simultaneously (i.e., during the same burial event, see Figure 5, bottom and side).

3304-02
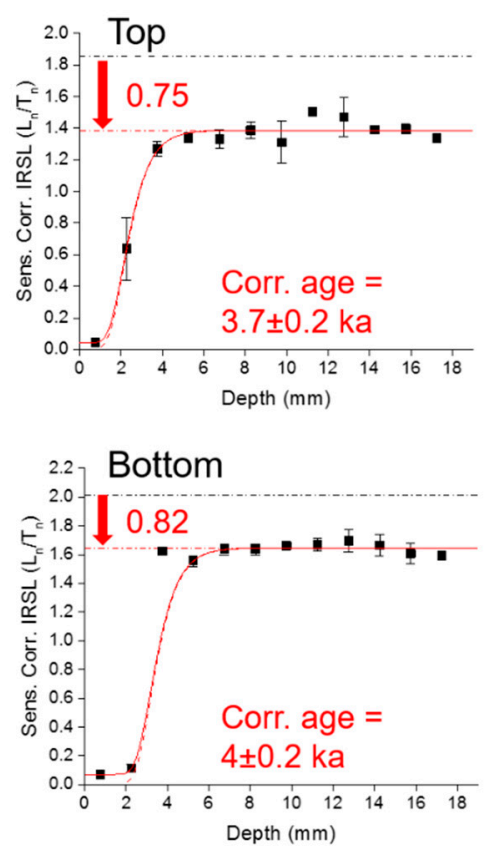

3304-06
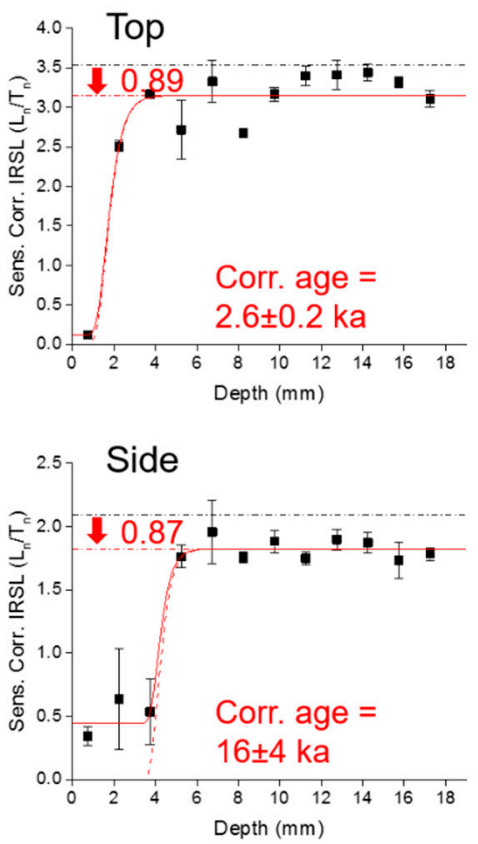

3305-05
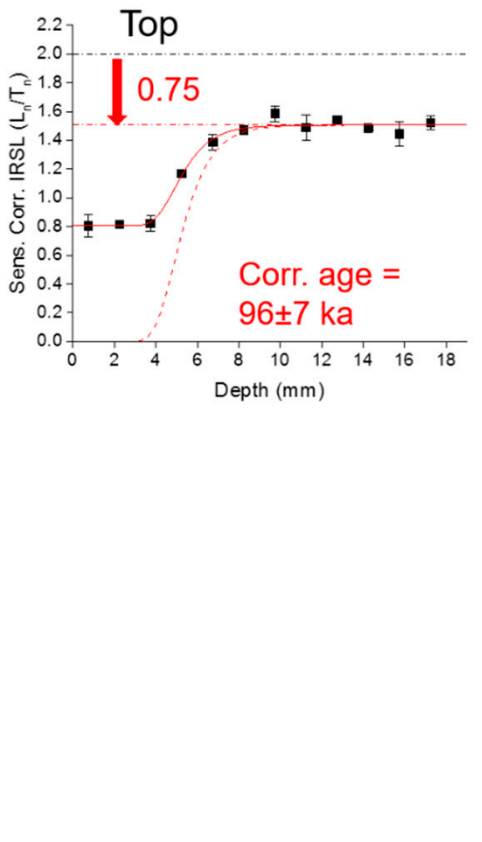

Figure 5. Luminescence profiles from apparently well-bleached surfaces. The best fit of the model by Sohbati et al. [54] is shown as a solid line and the predicted latent luminescence profile at the time of burial is shown as a dashed line. The black and red dash-dot lines represent the laboratory and field saturation limits, respectively. The field-to-laboratory saturation ratios shown next to arrows provide an upper limit to fading and were used to correct the ages after Rades et al. [63].

Based on the preliminary luminescence measurements, clasts 3304-2, 3304-6, and 3305-5 were prepared for radionuclide analysis, as discussed above. The resulting concentrations, along with those from the surrounding sediment samples, are summarized in Table 3, together with the derived infinite matrix dry beta and gamma dose rates. 
Table 3. Radionuclide concentrations and dry infinite matrix dose rates for selected samples.

\begin{tabular}{ccccccc}
\hline $\begin{array}{c}\text { Sample } \\
\text { Code }\end{array}$ & ${ }^{238} \mathbf{U ~ B q} / \mathbf{k g}$ & ${ }^{226} \mathbf{R a ~ B q} / \mathbf{k g}$ & ${ }^{232} \mathbf{T h} \mathbf{B q} / \mathbf{k g}$ & ${ }^{40} \mathbf{K ~ B q} / \mathbf{k g}$ & $\begin{array}{c}\boldsymbol{\beta} \text { Dose Rate, } \\
\text { Gy/ka }\end{array}$ & $\begin{array}{c}\boldsymbol{\gamma} \text { Dose Rate, } \\
\text { Gy/ka }\end{array}$ \\
\hline $3304-02$ & $10 \pm 1$ & $11.9 \pm 0.2$ & $12.28 \pm 0.16$ & $84 \pm 2$ & $0.430 \pm 0.010$ & $0.314 \pm 0.010$ \\
$3304-06$ & $19 \pm 1$ & $19.3 \pm 0.2$ & $5.57 \pm 0.13$ & $52 \pm 2$ & $0.387 \pm 0.014$ & $0.273 \pm 0.016$ \\
$3305-05$ & $4 \pm 3$ & $7.3 \pm 0.3$ & $7.3 \pm 0.3$ & $180 \pm 6$ & $0.586 \pm 0.016$ & $0.291 \pm 0.009$ \\
Sed 4 & $22 \pm 5$ & $20.9 \pm 0.4$ & $25.1 \pm 0.5$ & $373 \pm 9$ & $1.319 \pm 0.027$ & $0.735 \pm 0.020$ \\
Sed 5 & $14 \pm 4$ & $17.6 \pm 0.3$ & $18.4 \pm 0.3$ & $221 \pm 6$ & $0.858 \pm 0.019$ & $0.514 \pm 0.016$ \\
\hline
\end{tabular}

The sediment sample Sed 4 is associated with cobbles 3304-02 and 3304-06 and sediment sample Sed 5 comes from the surrounding of cobble 3305-05.

For each surface slice, we assume the total beta dose rate is made up of the sum of $80 \%$ of the dose rate from within the clast, and $20 \%$ of the dose rate from the surrounding sediment [64]. In the case of the gamma dose rate we assumed that the sediment and the clast each contributed $50 \%$ to the total based on visual inspection. Water content within the clasts was negligible, and that in the surrounding sediment was taken as $5 \%$ on average. These values produced a small perturbation on the individual dose rates of $<2 \%$. Finally the cosmic ray dose rates were added to the total to give the total dose rates presented in Table 4 below.

Table 4. Sample data, equivalent dose, dose rate estimates, and resulting luminescence ages.

\begin{tabular}{cccccccc}
\hline Sample Code & $\begin{array}{c}\text { Depth } \\
\text { [cm] }\end{array}$ & Dose [Gy] & $n^{*}$ & $\begin{array}{c}\text { Apparent } \\
\text { Age [ka] }\end{array}$ & $\begin{array}{c}\text { Dose Rate } \\
\text { [Gy/ka] }\end{array}$ & $\begin{array}{c}\text { Age Correction } \\
\text { Factor *** }\end{array}$ & $\begin{array}{c}\text { Corrected } \\
\text { Age [ka] }\end{array}$ \\
\hline $3304-02$ top & 275 & $6.2 \pm 0.3$ & 12 & $2.8 \pm 0.2$ & $2.24 \pm 0.08$ & 0.75 & $3.7 \pm 0.2$ \\
\hline $3304-02$ bottom & 275 & $7.4 \pm 0.3$ & 10 & $3.3 \pm 0.2$ & $2.24 \pm 0.08$ & 0.82 & $4 \pm 0.2$ \\
\hline $3304-06$ top & 275 & $5.8 \pm 0.3$ & 6 & $2.4 \pm 0.2$ & $2.44 \pm 0.09$ & 0.89 & $2.6 \pm 0.2$ \\
\hline $3304-06$ side & 275 & $34 \pm 9$ & 3 & $14 \pm 4$ & $2.44 \pm 0.09$ & 0.87 & $16 \pm 4$ \\
\hline $3305-05$ top & 275 & $164 \pm 11$ & 14 & $74 \pm 6$ & $2.22 \pm 0.08$ & 0.75 & $96 \pm 7$ \\
\hline
\end{tabular}

$*$ ' $n$ ' is the number of individual measurements of dose used to derive the average given in column 3 ; ** the dose rate data are derived from the individual radionuclide concentrations given in Table 2; ${ }^{* * *}$ Age correction factor based on the fraction of signal remaining at field saturation [63].

Our data only supported the assumption of one exposure event followed by one burial event, for each profile. The data of Figure 5 were thus fitted using the model developed by Freiesleben et al. [65]. From the predicted initial luminescence profiles it could be seen that it was likely that at least $1-2 \mathrm{~mm}$ of each rock surface was fully reset at the time of burial. This gives us confidence that at least some of the surface layers of these clasts should record the last burial time of the clast. Note that this was not necessarily the last transport event, because it was possible for a previously light-exposed surface to be moved and deposited in a turbid event without further daylight exposure.

The data of Figure 5 demonstrate that clasts 3304-2, 3304-6, and 3305-5 were exposed to sufficient daylight to reset the latent luminescence in the surfaces of the clasts to zero. We therefore resampled additional material from the outer $1.2 \mathrm{~mm}$ of each and measured the apparent doses recorded by these slices using the protocol outlined in Table 1. These measurements gave the burial doses (equivalent doses, $\mathrm{D}_{\mathrm{e}}$ ) summarized in column 3 of Table 4. Dividing these apparent doses by the total dose rates in column 6 gives the time since last daylight bleaching (column 5). It was immediately apparent that the two surfaces of 3304-2 and one surface of 3304-6 gave comparable ages of $2.4 \mathrm{ka}$ to $3.3 \mathrm{ka}$, whereas one surface of 3304-6 was apparently last exposed to daylight $~ 14$ ka ago. The only plausible explanation for the age difference is that, during its last light (or surface) exposure, the lateral face of cobble 3304-06 remained buried within the mudflow matrix and the exposure event was of relatively short duration.

Cobble 3305(-5) from site 5 (i.e., pediment-glacis-complex) gave an apparent age of $74 \pm 6 \mathrm{ka}$. This OSL age is older than the existing ${ }^{10} \mathrm{Be}$ age constraints for the interpolated main glacis surface in the upper Valle de la Fueva Baja (cf. Stange et al. [18]). We assumed that cobble 3305 was last exposed to 
daylight around $74 \pm 6 \mathrm{ka}$ and subsequently buried within a mudflow matrix without any significant light exposure.

It is important to realize that, from a methodological perspective, these are well-defined OSL ages, which are not the arbitrary result of poor bleaching. The profiles of Figure 5 give us confidence that the grains on these surfaces were fully reset immediately prior to absorbing the most recent burial dose. However, since ages are based on the relatively unstable $\mathrm{IR}_{50}$ signal, age corrections were applied (cf. column 8, Table 4) after Rades et al. [63], by comparing the field saturated signal (from the inner parts of the profiles in Figure 5) with a laboratory saturated signal of 2 kGy for which the time since irradiation is too short for instability to affect the signal.

\subsection{TCN Catchment Erosion Rates}

Using parameters and sample data presented in Tables 1 and $5,{ }^{10} \mathrm{Be}$ concentrations were measured from Quartz in bedload samples collected at the outlets of the Valle de la Fueva Baja and of the Natiella subcatchments (Figure 2). Our calculations yielded ${ }^{10} \mathrm{Be}$ catchment erosion (denudation) rates ranging from $47-96 \mathrm{~mm} \mathrm{kyr}^{-1}$ (Table 5). These catchment denudation rates are in line with previously published data sets for non-glaciated drainage basins in central Europe (e.g., $10-100 \mathrm{~mm} \mathrm{kyr}^{-1}$ on 10-100 kyr time scales; [44]), considering that they reflect late- to postglacial catchment erosion on 10-20 kyr timescales. These timescales are based on the "apparent" ${ }^{10}$ Be exposure ages, i.e., $10 \pm 1.1 \mathrm{ka}$ for Natiella and $20 \pm 2.1$ ka for Fueva Baja outlet samples, respectively. And yet, it is obvious that the Natiella catchment erosion rate $\left(96 \pm 9.8 \mathrm{~mm} \mathrm{kyr}^{-1}\right)$ is about twice the rate obtained for the Valle de la Fueva Baja $\left(47.3 \pm 4.4 \mathrm{~mm} \mathrm{kyr}^{-1}\right)$. A brief review of parameter assumptions may help to resolve this apparent discrepancy. Valid assumptions are that the denudation time scale is smaller than the time scale for ${ }^{10}$ Be radioactive decay (i.e., $\varepsilon>0.3 \mathrm{~mm} \mathrm{kyr}^{-1}$; [44]) and that sediment storage in the Valle de la Fueva is minimal, considering the only $5 \%$ in-channel sediment storage in the adjacent highly erodible Isábena catchment (e.g., [16]). Moreover, Fueva Baja and Fueva Alta catchments naturally share the same spatial scaling and climatic setting (e.g., precipitation, vegetation, etc.), and approximately the same geological setting.

Table 5. Bedload sediment sample data and AMS results used for producing ${ }^{10} \mathrm{Be}$ catchment wide erosion rates with CRONUS-Earth online calculator 2.3. Scaling scheme applied: Lal [43]/Stone [51]. Samples were spiked with SCHARLAU Be standard solution $1000 \mathrm{mg} / \mathrm{L}$.

\begin{tabular}{|c|c|c|c|c|c|c|c|c|}
\hline $\begin{array}{l}\text { Sample } \\
\text { ID }\end{array}$ & $\begin{array}{c}\text { Qtz. Mass } \\
\text { Dissolved [g] }\end{array}$ & $\begin{array}{l}\text { Mass }{ }^{9} \mathrm{Be} \\
\text { Carrier }[\mathrm{g}]\end{array}$ & ${ }^{10} \mathrm{Be} /{ }^{9} \mathrm{Be}$ & $\begin{array}{c}\text { Conc. }{ }^{10} \mathrm{Be} \\
\text { [at } \mathrm{g}^{-1} \text { ] }\end{array}$ & $\begin{array}{c}\text { Uncert. }{ }^{10} \mathrm{Be} \\
{\left[\text { at } \mathrm{g}^{-1}\right]}\end{array}$ & $\begin{array}{l}\text { Erosion Rate } \\
{\left[\mathrm{g} \mathrm{cm}^{-2} \mathrm{yr}^{-1}\right]}\end{array}$ & $\begin{array}{c}\text { Erosion Rate } \\
{\left[\mathrm{mm} \mathrm{kyr}{ }^{-1}\right]}\end{array}$ & $\begin{array}{c}\text { Uncert. } \\
{\left[\mathrm{mm} \mathrm{kyr}^{-1}\right]}\end{array}$ \\
\hline S-45 & 11.8056 & $3.022 \times 10^{-4}$ & $6.975 \times 10^{-14}$ & $116,762.7$ & 5044.15 & 0.00947 & 47.35 & 4.42 \\
\hline S-48 & 8.9154 & $3.022 \times 10^{-4}$ & $2.744 \times 10^{-14}$ & $59,118.64$ & 3440.70 & 0.01920 & 96.02 & 9.79 \\
\hline
\end{tabular}

Factors that potentially explain the inconsistent catchment-wide erosion rates are differences in basin topography (e.g., local relief, hillslope gradients, [66,67]), non-uniform distribution of quartz-bearing lithologies, and the catchments' base level history and sediment residence time, i.e., the "apparent" exposure age of the sediment source rock. For comparison with von Blanckenburg's [44] compilation of world-wide denudation rates in non-glaciated areas, topographic relief was calculated as mean catchment altitude minus minimum altitude, i.e., $258 \mathrm{~m}$ and $152 \mathrm{~m}$ for Fueva Baja and Natiella, respectively. It turns out that the Fueva Baja catchment denudation rate $\left(47.3 \pm 4.4 \mathrm{~mm} \mathrm{kyr}^{-1}\right)$ represents a typical example of a middle European mountain catchment whereas the Natiella subcatchment $\left(96 \pm 9.8 \mathrm{~mm} \mathrm{kyr}^{-1}\right)$ plots between middle European and alpine catchments. To which extent individual catchment size and local relief represents an important scaling factor in the Valle de la Fueva has not been clarified due to the limited number of samples and because bedload material in the remaining (sub-) catchments was not suitable for ${ }^{10} \mathrm{Be}$ analyses due to the lack of quartz. Besides local differences in basin slope and relief [66,67], the catchments' different base level histories and sediment residence times may exert a principle control on the inconsistent catchment erosion rates. The Natiella catchment is an open lateral tributary catchment of the Río de la Nata that drains the Valle de la Fueva Alta and 
is directly base level connected to the main river Cinca. In the Valle de la Fueva Baja, however, late stage fluvial incision and sediment transfer towards the Cinca is controlled (and potentially delayed) by a narrow outlet canyon with prominent bedrock knickpoints [18]. This implies that the sediment residence time in the Fueva Baja could be significantly longer than in the smaller and steeper Natiella subcatchment. Moreover, as for the Natiella catchment, base level lowering at the Fueva Alta outlet would have much more immediate effects, triggering rapid fluvial incision and sediment transfer to the Río de la Nata and Cinca River, respectively (Figure 2). This reasoning is in accordance with the "apparent" exposure ages and ${ }^{10} \mathrm{Be}$ concentrations measured in the outlet bedload samples (Table 5). Hence, it can be inferred that on a 10-20 kyr timescale sediment routing and internal sediment residence time in the Valle de la Fueva are non-uniform.

\subsection{Eroded Sediment Volumes}

As inferred from ${ }^{10} \mathrm{Be}$ exposure data, morphogenetic relationships, and the resulting paleo-topographic reconstructions [18], post-LGM erosion and sediment fluxes in both the Valle de la Fueva Alta (c. $100 \mathrm{~km}^{2}$ ) and in Valle de la Fueva Baja (c. $90 \mathrm{~km}^{2}$ ) were calculated from the missing (eroded) volumes with respect to the reconstructed Late-MIS 2 paleo-topography (i.e., the total excavated volume under the pediments). With the aid of field maps, absolute dating, and digital terrain analyses, topographic reconstructions were carried out in ArcGIS. Starting from interpolated polygon and point data, feature outline vertices from isolated remnant hills, pediments, and prominent barranco cut-bank cliffs (Figure 2), were extrapolated in order to produce interconnected Late-MIS 2 paleo-surfaces across the Valle de la Fueva (Figure 3).

GIS-based raster calculations yielded missing (eroded) sediment volumes of $1.5463 \mathrm{~km}^{3}$ on an area of $47.43 \mathrm{~km}^{2}$ for the Valle de la Fueva Alta, and $1.7411 \mathrm{~km}^{3}$ on $52.01 \mathrm{~km}^{2}$ for the Valle de la Fueva Baja, i.e., c. $3.3 \mathrm{~km}^{3}$ sediment loss on c. $100 \mathrm{~km}^{2}$ in total under the pediments. This corresponds to relatively consistent eroded sediment thicknesses of $32.60 \mathrm{~m}$ for the Valle de la Fueva Alta and $33.48 \mathrm{~m}$ for the Valle de la Fueva Baja. The reported eroded sediment thicknesses are spread out over areas affected by significant erosion as shown in Figure 5. This includes incised reaches, degraded slopes and pediment domains, and badland areas. Accepting the established abandonment of pediment surfaces and the onset of fluvial dissection around $18 \mathrm{ka}$ [18], eroded thicknesses can be converted into Late MIS 2-Holocene erosion rates of $1811 \mathrm{~mm} \mathrm{kyr}^{-1}$ for the Valle de la Fueva Alta and $1860 \mathrm{~mm} \mathrm{kyr}^{-1}$ for the Valle de la Fueva Baja. Excavated volumes and deduced erosion rates obtained for the Valle de la Fueva, however, can only serve as a first approximation due to uncertainties associated with the reconstructed Fueva Baja paleo-topography. Uncertainties include unconstrained initial cover sediment thicknesses, limited chronological control points, and potential inaccuracies owed to the scarce elevation reference points in the lower Fueva Baja catchment where only a few pediment remnants are preserved (Figure 2). Since quantification of uncertainties related to unpreserved sediments and features is difficult and largely speculative, the calculated missing volumes should be regarded as minimum estimates. Figure 6 shows the extent of areas affected by erosion since the rapid abandonment of extensive pedimentation plains (cf. black shades) after the Last Glacial Maximum; e.g., [18]. 'Eroded domains' hereby refer to areas characterized by volume net loss between the present-day DEM and the extrapolated paleo-topography. The principal late stage erosion phases were tentatively reconstructed based on TCN/OSL age constraints and morphogenetic classifications of syn/late-glacial glacis-pediment-units, Holocene badlands and degraded slopes, and late-Holocene terraces [18]. While early Holocene erosion phases are not well established (cf., grey shades), new OSL dating of the lowermost terraces in the Valle de la Fueva enable a first confinement of the magnitudes of late Holocene fluvial erosion (cf. Figure 6, pink shades). Eroded volumes were calculated at $0.01 \mathrm{~km}^{3}$ on an area of $4.6 \mathrm{~km}^{2}$ since approximately $4 \mathrm{ka}$, i.e., 2.17 m eroded thickness and an associated erosion rate of $543.5 \mathrm{~mm} \mathrm{kyr}^{-1}$. The orders of magnitudes in difference between late Holocene erosion and the total volumes excavated since Late-MIS 2 indicate that most of the sediment was excavated and transferred to the main channel Cinca in response to the last major climate transition and establishing Holocene interglacial conditions. 


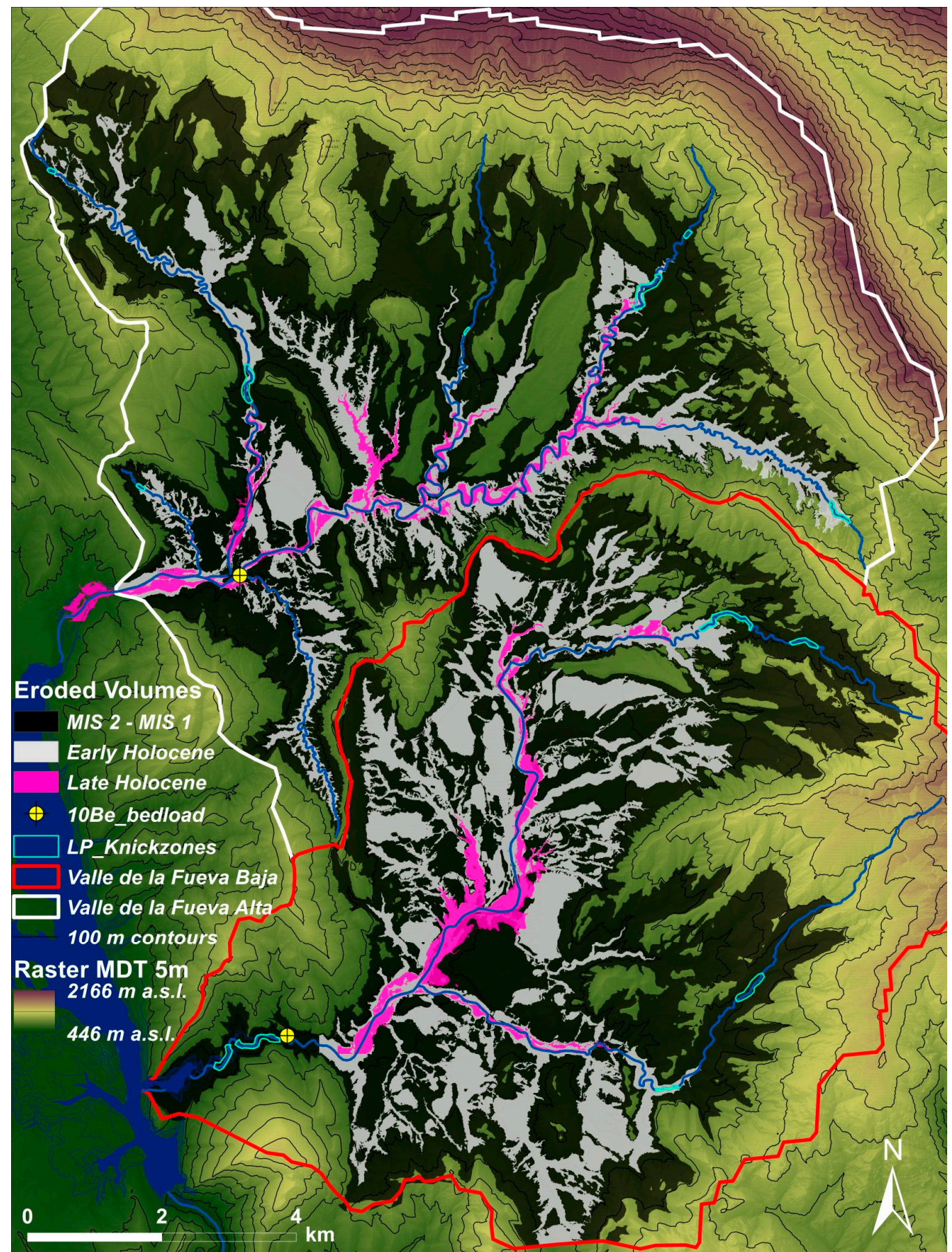

Figure 6. Erosion map of the Valle de la Fueva showing areas affected by net sediment loss (i.e., erosion) following pediment abandonment during Late MIS 2. Volumes are calculated with respect to established basin paleo surfaces reconstructed from pediments, glacis, and fluvial-cut terraces: (i) Late Holocene erosion within tributary ravines (pink); (ii) presumed early Holocene erosion marked by degraded pediment slopes, shallow and undulated erosion surfaces, and badland domains (grey); and (iii) domains eroded following gully piping and pediment abandonment, presumably during Late MIS 2 until early Holocene (black). This classification includes field observations allowing a first distinction of well-preserved pediment surfaces and degraded, undulated erosion surfaces with steeper slopes and very thin or lacking colluvial cover. 


\section{Discussion}

Despite the limited number of successful OSL samples, corrected ages (Table 4) serve as a first approximation of the age of late stage tributary terraces in the Valle de la Fueva. The three consistent sediment burial ages obtained for the fluvial-cut terrace at sampling site 3 (Figure 2, Table 4) gave us confidence that the latest fluvial downcutting episode recorded by the Fueva tributary terraces (2-4 m a.f.; Figure 4) happened relatively recently, after 3-4 ka. Furthermore, the last (lateral) light exposure of clast 3304-06 left (Table 4) was measured as $16 \pm 4 \mathrm{ka}$, giving some additional evidence for surface erosion and sediment transport at that time, e.g., [18]. Similar conclusions could be drawn from clast 3305-05 top (Table 4; location 4, Figure 2), which was last exposed to daylight at $96 \pm 7 \mathrm{ka}$, around the onset of the last cold climate cycle. OSL ages thus extend the established ${ }^{10} \mathrm{Be}$ chronology of Stange et al. [18] and provide additional chronological constraints on the latest incision phase in the ravines of Valle de la Fueva Alta after 3-4 ka.

With respect to radiometric terrace chronology of the main river Cinca [19], the latest fluvial incision phase recorded by the lower terraces scarps in the ravines of Valle de la Fueva is linked presumably to the downcutting of the youngest Quaternary terrace of the Cinca, i.e., ' $Q t^{\prime}$ ' 10, c. $0.8 \mathrm{ka}$ [19]. This indicates that base level lowering at the Río Cinca is a major driver of incision in the tributary rivers, at least in the base level adjusted Valle de la Fueva Alta [18], and yet, since OSL rock surface ages actually denote the timing of sediment transport and burial prior to the formation of the fluvial-cut terrace features, substantial sediment routing and bulk deposition in the Valle de la Fueva must have happened earlier, at or before $3-4$ ka.

This supports our previous findings that headwater catchment archives provide a much more detailed picture on surface process response to environmental changes than it is recorded in large scale fluvial systems like the Cinca River. The reason is that surface processes in the Valle de la Fueva headwater catchments are caused directly by in situ runoff and discharge fluctuations in response to local precipitation and environmental conditions [18]. This includes that changes in vegetation cover constitute an important parameter for sediment routing and erosion in the basin. Regional palynological data from the southern Pyrenees denote expansive steppe communities under cold and dry climatic conditions until approximately $15 \mathrm{ka}$ [68-70]. Surface levelling and denudation in the Valle de la Fueva, e.g., formation of pediments and glacis cover sediments, Ref. [18], was thus facilitated by an open vegetation cover. During the Bölling-Allerød-Interstadial, grass and steppe taxa declined and birch and pine trees became more abundant [68]. The expansion of forest communities during early Holocene warming in turn enhanced the resistance of the catchment to surface denudation and significantly delimited erosion pathways in the Valle de la Fueva, forcing linear fluvial erosion along the gullies and ravines. In this process large volumes of sediment were excavated and subsequently aggraded in the lower catchment areas. This is in line with López-Tarazón et al. [16] who investigated recent sediment transport in the adjacent highly erodible Isábena catchment and found that sediment storage increases towards the lower catchment areas. The isolated, flat-topped remnant hills and planation surfaces in the upper catchments, instead, remained protected from further degradation due to rapid expansion of stabilizing, dense forest communities on the shallow (mantled) pediment slopes. Around 4500-3900 cal yr BP [71], a significant decrease in arboreal pollen was recorded in the sedimentary sequence from Base de la Mora Lake which is situated at $1914 \mathrm{~m}$ a.s.l., about $10 \mathrm{~km}$ NE of the Valle de la Fueva. This period coincides with the mid Holocene "Thermal Maximum" (7500-4000 cal yr BP), which is marked by increased forest fires and intense flood episodes in the western Mediterranean region [72,73]. This provides a plausible explanation for Holocene sediment (re-) mobilization and erosion in the Valle de la Fueva and corroborates the OSL burial ages presented in this paper. Late stage fluvial downcutting and terrace formation in the Valle de la Fueva after 3-4 ka may in turn be linked to a climate-triggered increase in regional flood magnitudes between 3000-2000 cal yr BP [73], and/or to growing anthropogenic pressure, intensification of agriculture, and forest management after 1700 yr BP [74]. 
Considering the orders of magnitudes in difference between late Holocene erosion and the total (minimum) volumes excavated since Late-MIS 2 (cf. Section 4.3), one gets a glance of the profound landscape changes and dramatic erosion phases that occurred in the course of the last major climate transition at the onset of the Holocene. Although the timing of individual events remain uncertain, associated erosion waves must have rapidly propagated across the highly erodible Fueva headwater catchments once the extensive pediment-glacis were undermined and an initial network of rills and gullies was established [18]. Post-LGM sediment fluxes of in the $190 \mathrm{~km}^{2}$ Valle de la Fueva drainage basin (i.e., $>3.3 \mathrm{~km}^{3}$ ) and in the several subcatchments (cf. 4.3) are consistent with previous findings of a strong correlation between sediment flux and mountain catchment size [28] indicating that intra-basin sediment storage is generally low and sediment is delivered quickly to the main river. This is in line with previous research on the adjacent highly erodible Isábena catchment in the southern Pyrenees where in-channel sediment storage is only about $5 \%$ [16].

${ }^{10} \mathrm{Be}$ catchment denudation rates in the Valle de la Fueva were relatively low for a highly erodible drainage basin. Since ${ }^{10} \mathrm{Be}$ was measured from quartz, they are only valid for homogeneous quartz-bearing lithologies within the catchments. This was the case for the upstream catchment areas of the Valle de la Fueva Baja and the Natiella subcatchments, which was chosen as target catchments. However, taking into account the generally large proportion of highly erodible sediments and marls across the lower catchment areas, ${ }^{10} \mathrm{Be}$ catchment erosion rates were likely underestimated and should be regarded as minimum estimates. Nevertheless, they were comparable to arid region drainage basins and plot around the median of global drainage basin $\left({ }^{10} \mathrm{Be}\right)$ denudation rates (i.e., $54 \mathrm{~m} \mathrm{My}^{-1}$, [67]). Regionally, they represented a typical example of Iberian mountain catchments with denudation rates having the same order of magnitude as in the northern Pyrenees (e.g., $100 \mathrm{~mm} \mathrm{kyr}^{-1}$, [75]) and in catchments of the Betic mountain chain (e.g., 14-246 mm kyr ${ }^{-1}$, [66]). In addition, averaged ${ }^{10} \mathrm{Be}$ catchment denudation rates of $0.014 \mathrm{~g} \mathrm{~cm}^{-2} \mathrm{yr}^{-1}$ (cf. Table 5) for the Valle de la Fueva have the same order of magnitude as the modern mean sediment yield in the adjacent Isábena catchment of $0.058 \mathrm{~g} \mathrm{~cm}^{-2} \mathrm{yr}^{-1}$ [16]. Since sediment yield typically increases with catchment size, the much larger Isábena basin area $\left(445 \mathrm{~km}^{2}\right)$ compared to the $190 \mathrm{~km}^{2}$ of La Fueva, explains the much higher sediment delivery of the Isábena catchment with respect to the Valle de la Fueva. The measured ${ }^{10} \mathrm{Be}$ catchment denudation rates thus clearly reflect a present-day situation with limited informative value as to the magnitudes of sediment fluxes during erosion phases in response to the last major climate transition and the early Holocene.

Instead, eroded sediment volumes derived from paleo-topographic reconstructions give useful insight into the magnitudes and variability of sediment fluxes over time, even though their accuracy may be deficient depending on the preservation of geomorphic features and associated age controls. Volumetric calculations for the excavated sediments in the Valle de la Fueva main catchments yield comparable values of $32.60 \mathrm{~m}$ and $33.48 \mathrm{~m}$ eroded sediment thickness for the Fueva Alta and Fueva Baja catchments since the abandonment of pediment surfaces at the end of MIS 2. This corresponds to erosion rates of $1811 \mathrm{~mm} \mathrm{kyr}^{-1}$ and $1860 \mathrm{~mm} \mathrm{kyr}^{-1}$, respectively, which is about 20-40 times higher than the ${ }^{10} \mathrm{Be}$ catchment-wide erosion rates (cf. Table 5). With regard to the existing physical evidence and spatial-temporal constraints for the volumetric erosion rates, they represented a much better approximation of the actual magnitudes of erosion phases in the course of the major climate transition at the end of MIS 2. As for the calculations of late Holocene eroded sediment thickness (i.e., $2.17 \mathrm{~m}$ on $\sim 4 \mathrm{kyr}$ ) and respective erosion rates $\left(543.5 \mathrm{~mm} \mathrm{kyr}^{-1}\right)$, rates were in good agreement with recent values from the adjacent Isábena catchment [16,17], and they depicted reasonable values for Mediterranean highly erodible mountain catchments $[17,66,75]$. We therefore conclude that catchment erosion rates based on time-dependent paleo-topographic reconstructions and absolute dating adequately reflect the magnitudes of paleo-environmental changes, whereas ${ }^{10} \mathrm{Be}$ catchment erosion rates are more useful for longer averaging time scales and steadily eroding landscapes. 


\section{Conclusions}

This study has shown that mountain headwater catchments were excellent terrains for investigating the direct effects of climate change on surface processes and landscape evolution. In combination, morphogenetic mapping, DEM-based paleo-topographic reconstructions, and absolute exposure/burial dating of rocks and sediment sequences were a useful tool set for assessing and quantifying erosion processes in intramontane drainage basins. Most strikingly, non-glaciated mountain catchments like the Valle de la Fueva had distinct cold- and warm-climate geomorphic features preserved whose morphogenetic development reflects contrasting paleo-environmental conditions, even across major climate transitions.

Considering previously published ${ }^{10} \mathrm{Be}$ exposure ages of Stange et al. [18], a (late stage) catchment erosion model for the Valle de la Fueva comprised of the following development stages: (i) Formation of extensive pediment-glacis complexes and lasting surface denudation under cold-climate conditions from MIS 4-2, (ii) rapid fluvial dissection and downcutting of ravines during the last major climate transition and establishing interglacial conditions, (iii) substantial sediment routing towards the basin depo centers caused by intense flood episodes and frequent forest fires in response to the mid Holocene "Thermal Maximum", and (iv) late stage fluvial incision after 3-4 ka due to climate-triggered increased flood magnitudes in the region and/or intensification of agriculture and forest management.

The analysis of topography, erosion patterns and sediment fluxes in the Valle de la Fueva indicated that the styles and magnitudes of surface processes in headwater catchments were directly correlated with the amplitude and nature of climate change, modified by the specific interplay of environmental parameters like, for instance, bedrock and surface lithology, local precipitation, base level lowering, vegetation dynamics, and land use. In contrast to large-scale fluvial systems, mountain headwater catchments were much less afflicted with temporal and spatial averaging biases, allochthonous discharge, and sediment input. Methodologically, erosion rates based on paleo-topographic reconstructions combined with absolute dating were proven to produce better approximations of the actual magnitudes of late-stage erosion phases than averaged catchment-wide ${ }^{10} \mathrm{Be}$ erosion rates. Our study has shown, that non-glaciated headwater catchments were useful targets for investigating environmental changes and direct surface process response to major climate change and extreme climatic events. By nature, climate regimes are characterized by long-term cyclicity and short-term non-linearity, the latter of which has been shown to be a major factor in landscape development in the southern Pyrenees. Despite being somewhat underrepresented in fluvial system research, non-glaciated mountain headwater catchments like the Valle de la Fueva provide important insight into the direct coupling and non-linearity of surface processes in Quaternary fluvial systems.

Author Contributions: Conceptualization, K.M.S., I.M., and J.P.N.; Methodology, K.M.S., R.S., A.M., and W.T.; Investigation, K.M.S., I.M., J.P.N., R.S., and A.M.; Data Curation, K.M.S.; Writing-Original Draft Preparation, K.M.S. and W.T.; Writing-Review \& Editing, C.S. and H.-J.K.; Project Administration, K.M.S.; Funding Acquisition, K.M.S.

Funding: This research project was carried out with the support of the University of Bremen and the European Union FP7 COFUND under BremenTRAC grant agreement number 600411. A pilot study was possible through funding from the European Science Foundation TopoEurope project PYRTEC. Considerable parts of fieldwork and absolute sediment dating during this research initiative was financed by the German Science Foundation DFG (GZ-STA1474/1-1).

Acknowledgments: We would like to thank in particular Cai Puigdefábregas whose fieldwork collaboration and counselling added a great deal of value to this study. We also thank Damia Vericat (University of Lleida), Warren Thompson (Aarhus University), Steve Binnie and Elena Voronina (Cologne University) for their advice and technical support.

Conflicts of Interest: The authors declare no conflict of interest. The founding sponsors had no role in the design of the study; in the collection, analyses, or interpretation of data; in the writing of the manuscript, and in the decision to publish the results. 


\section{References}

1. Vandenberghe, J. Timescales, climate and river development. Quat. Sci. Rev. 1995, 14, 631-638. [CrossRef]

2. Vandenberghe, J. The relation between climate and river processes, landforms and deposits during the Quaternary. Quat. Int. 2002, 91, 17-23. [CrossRef]

3. Maddy, D.; Bridgland, D.; Westaway, R. Uplift-driven valley incision and climate controlled river terrace development in the Thames Valley, UK. Quat. Int. 2001, 79, 23-36. [CrossRef]

4. Tucker, G.E. Drainage basin sensitivity to tectonic and climatic forcing: Implications of a stochastic model for the role of entrainment and erosion thresholds. Earth Surf. Proc. Landf. 2004, 29, 185-205. [CrossRef]

5. Merritts, D.J. Fluvial Environments | Terrace Sequences. In Encyclopedia of Quaternary Science; Elsevier: Amsterdam, The Netherlands, 2007; pp. 694-704.

6. Bridgland, D.; Westaway, R. Climatically controlled river terrace staircases: A worldwide Quaternary phenomenon. Geomorphology 2008, 98, 285-315. [CrossRef]

7. Garcia-Castellanos, D.; Vergés, J.; Gaspar-Escribano, J.; Cloetingh, S. Interplay between tectonics, climate and fluvial transport during the Cenozoic evolution of the Ebro Basin (NE Iberia). J. Geophys. Res. 2003, 108, 2347-2364. [CrossRef]

8. Stange, K.M.; Van Balen, R.T.; Garcia-Castellanos, D. Numerical modelling of terrace staircase formation in the Quaternary drainage system of the southern Pyrenees, Ebro basin, NE Iberia. Basin Res. 2014, 28, 124-146. [CrossRef]

9. Cordier, S.; Briant, B.; Bridgland, D.; Herget, J.; Maddy, D.; Mather, A.; Vandenberghe, J. The Fluvial Archives Group: 20 years of research connecting fluvial geomorphology and palaeoenvironments. Quat. Sci. Rev. 2017, 166, 1-9. [CrossRef]

10. Cordier, S.; Adamson, K.; Delmas, M.; Calvet, M.; Harmand, D. Of ice and water: Quaternary fluvial response to glacial forcing. Quat. Sci. Rev. 2017, 166, 57-73. [CrossRef]

11. Merritts, D.J.; Vincent, K.R.; Wohl, E.E. Long river profiles, tectonism, and eustasy: A guide to interpreting fluvial terraces. J. Geophys. Res. 1994, 99, 14031-14050.

12. Cheetham, M.D.; Bush, R.T.; Keene, A.F.; Erskine, W.D. Nonsynchronous, episodic incision: Evidence of threshold exceedance and complex response as controls of terrace formation. Geomorphology 2010, 123, 320-329. [CrossRef]

13. Temme, A.J.A.M.; Keiler, M.; Karssenberg, D.; Lang, A. Complexity and non-linearity in earth surface processes-Concepts, methods and applications. ESEX Commentary. Earth Surf. Proc. Landf. 2015, 40, 1270-1274. [CrossRef]

14. Mather, A.E. Impact of headwater river capture on alluvial system development: An example from the Plio-Pleistocene of the Sorbas Basin, SE Spain. J. Geol. Soc. 2000, 157, 957-966. [CrossRef]

15. Mather, A.E.; Stokes, M. Bedrock structural control on catchment-scale connectivity and alluvial fan processes, High Atlas Mountains, Morocco. In Geology and Geomorphology of Alluvial and Fluvial Fans: Terrestrial and Planetary Perspectives; Ventra, D., Clarke, L.E., Eds.; Geological Society Special Pub: London, UK, 2018; p. 440.

16. López-Tarazón, J.A.; Batalla, R.J.; Vericat, D.; Francke, T. The sediment budget of a highly dynamic mesoscale catchment: The River Isábena. Geomorphology 2012, 138, 15-28. [CrossRef]

17. Francke, T.; Werb, S.; Sommerer, E.; López-Tarazón, J.A. Analysis of runoff, sediment dynamics and sediment yield of subcatchments in the highly erodible Isábena catchment, Central Pyrenees. J. Soils Sediments 2014, 14, 1909-1920. [CrossRef]

18. Stange, K.M.; Midtkandal, I.; Nystuen, J.P.; Kuss, H.-J.; Spiegel, C. Direct response of small non-glaciated headwater catchments to Late Quaternary climate change: The Valle de la Fueva, southern Pyrenees. Geomorphology 2018, 318, 187-202. [CrossRef]

19. Lewis, C.J.; McDonald, E.V.; Sancho, C.; Peña, J.L.; Rhodes, E.J. Climatic implications of correlated upper Pleistocene glacial and fluvial deposits on the Cinca and Gállego Rivers (NE Spain) based on OSL dating and soil stratigraphy. Glob. Planet. Chang. 2009, 67, 141-152. [CrossRef]

20. Calvet, M.; Delmas, M.; Gunnel, Y.; Braucher, R.; Bourlès, D. Recent advances in research on Quaternary glaciations in the Pyrenees. In Quaternary Glaciations, Extent and Chronology. Part IV: A Closer Look; Ehlers, J., Gibbard, P.L., Eds.; Elsevier: Amsterdam, The Netherlands, 2011; pp. 127-139.

21. Hughes, P.D.; Gibbard, P.L.; Woodward, J.C. Quaternary glacial history of the Mediterranean Mountains. Prog. Phys. Geogr. 2006, 30, 334-364. [CrossRef] 
22. Woodward, J.C.; Hamlin, R.H.B.; Macklin, M.G.; Hughes, P.D.; Lewin, J. Glacial activity and catchment dynamics in northwest Greece: Longterm river behaviour and the slackwater sediment record for the last glacial to interglacial transition. Geomorphology 2008, 101, 44-67. [CrossRef]

23. Wenzens, E.; Wenzens, G. The influence of tectonics, sea-level fluctuations and river capture on the Quaternary morphogenesis of the semi-arid Pulpi Basin (southeast Spain). Catena 1997, 30, 283-293. [CrossRef]

24. Stokes, M.; Mather, A.E.; Belfoul, M.; Faik, F.; Bouzid, S.; Geach, M.R.; Cunha, P.P.; Bouton, S.J.; Thiel, C. Controls on dryland mountain landscape development along NW Saharan desert margins: Insights from Quaternary river terrace sequences (Dadès River, south-central High Atlas, Morocco). Quat. Sci. Rev. 2017, 166, 363-379. [CrossRef]

25. Cloetingh, S.; Willet, S.D. TOPO-EUROPE: Understanding of the coupling between the deep Earth and continental topography. Tectonophysics 2013, 602, 1-14. [CrossRef]

26. Braucher, R.; Blard, P.-H.; Benedetti, L.; Bourlès, D.L. Extending 10Be applications to carbonate-rich and mafic environments. In In Situ-Produced Cosmogenic Nuclides and Quantifi cation of Geological Processes; Siame, L., Bourlès, D.L., Brown, E.T., Eds.; Geological Society of America: Bolder, CO, USA, 2006; pp. 17-28. [CrossRef]

27. Dunai, T.J. Cosmogenic nuclides. In Principles, Concepts and Applications in the Earth Surface Sciences; Cambridge University Press: Cambridge, UK, 2010.

28. Portenga, E.W.; Bierman, P.R.; Duncan, C.; Corbett, L.B.; Kehrwald, N.M.; Hood, D.H. Erosion rates of the Bhutanese Himalaya determined using in situ-produced 10Be. Geomorphology 2015, 233, 112-126. [CrossRef]

29. Murray, A.S.; Olley, J.M. Precision and accuracy in the optically stimulated luminescence dating of sedimentary quartz: a status review. Geochronometria 2002, 21, 1-16.

30. Cordier, S. Optically stimulated luminescence dating: Procedures and applications to geomorphological research in France. Géomorphol. Relief Proc. Environ. 2010, 16, 21-40. [CrossRef]

31. Sohbati, R.; Murray, A.S.; Porat, N.; Jain, M.; Avner, U. Age of a prehistoric “Rodedian" cult site constrained by sediment and rock surface luminescence dating techniques. Quat. Geochronol. 2015, 30, 90-99. [CrossRef]

32. De Long, S.B.; Arnold, L.J. Dating alluvial deposits with optically stimulated luminescence, AMS 14 C and cosmogenic techniques, western Transvers Ranges, California, USA. Quat. Geochronol. 2007, 2, 129-136. [CrossRef]

33. Pallàs, R.; Rodés, A.; Braucher, R.; Bourlès, D.; Delmas, M.; Calvet, M.; Gunnel, Y. Small, isolated catchments as priority targets for cosmogenic surface exposure dating of Pleistocene climate fluctuations, south-eastern Pyrenees. Geology 2010, 38, 891-894. [CrossRef]

34. Demoulin, A.; Mather, A.; Whittaker, A. Fluvial archives, a valuable record of vertical crustal deformation. Quat. Sci. Rev. 2016, 166, 10-37. [CrossRef]

35. Puigdefábregas, C.; Muñoz, J.A.; Marzo, M. Thrust belt development in the eastern Pyrenees and related depositional sequences in the southern foreland basin. In Foreland Basins. International Association of Sedimentologists Series; Allen, P., Homewood, P., Eds.; Wiley: London, UK, 1986; pp. 229-246.

36. Pickering, K.T.; Bayliss, N.J. Deconvolving tectono-climatic signals in deep-marine siliciclastics, Eocene Ainsa basin, Spanish Pyrenees: Seesaw tectonics versus eustasy. Geology 2009, 37, 203-206. [CrossRef]

37. Michael, N.A.; Whittaker, A.C.; Carter, A.; Allen, P.A. Volumetric budget and grain-size fractionation of a geological sediment routing system: Eocene Escanilla Formation, South-Central Pyrenees. Geolog. Soc. Am. Bull. 2014, 126, 585-599. [CrossRef]

38. Muñoz, J.A.; Arbués, P.; McClay, K.; Butillé, M. Structural Evolution of the Ainsa Deep Water Fold and Thrust Belt in the Central Pyrenees and Syn-Tectonic Evolution of the Related Sedimentary Systems; Society of Exploration Geophysicists: Tulsa, OK, USA, 2015.

39. Muñoz, J.-A.; Beamud, E.; Fernández, O.; Arbués, P.; Dinarès-Turell, J.; Poblet, J. The Ainsa Fold and thrust oblique zone of the central Pyrenees: Kinematics of a curved contractional system from paleomagnetic and structural data. Tectonics 2013, 32, 1142-1175. [CrossRef]

40. Peña, J.L. La Conca de Tremp y Sierras Prepirenaicas comprendidas entre los Ríos Segre y Noguera Ribagorzana: Estudio Geomorfologico; Instituto de Estudios ILerdenses Diputacion Provincial de Lerida: Lerida, Spain, 1983.

41. Gosse, J.C.; Phillips, F.M. Terrestrial in situ cosmogenic nuclides: theory and application. Quat. Sci. Rev. 2001, 20, 1475-1560. [CrossRef]

42. Balco, G.; Rovey, C.W. An isochron method for cosmogenic nuclide dating of buried soils and sediments. Am. J. Sci. 2008, 308, 1083-1114. [CrossRef] 
43. Lal, D. Cosmic ray labeling of erosion surfaces: In situ nuclide production rates and erosion models. Earth Planet. Sci. Lett. 1991, 104, 424-439. [CrossRef]

44. Blanckenburg, F.V. The control mechanisms of erosion and weathering at basin scale from cosmogenic nuclides in river sediment. Earth Planet. Sci. Lett. 2005, 237, 462-479. [CrossRef]

45. Ahnert, F. Functional relationships between denudation, relief, and uplift in large mid-latitude drainage basins. Am. J. Sci. 1970, 268, 243-263. [CrossRef]

46. Brown, E.T.; Stallard, R.F.; Larsen, M.C.; Raisbeck, G.M.; Yiou, F. Denudation rates determined from the accumulation of in situ produced 10Be in the Luquillo Experimental forest, Puerto Rico. Earth Planet. Sci. Lett. 1995, 129, 193-202. [CrossRef]

47. Granger, D.E.; Kirchner, J.W.; Finkel, R. Spatially averaged long-term erosion rates measured from in-situ produced cosmogenic nuclides in alluvial sediment. J. Geol. 1996, 104, 249-257. [CrossRef]

48. Binnie, S.A.; Dunai, T.J.; Voronina, E.; Goral, T.S.; Dewald, A. Separation of Be and Al for AMS using single-step column chromatography. Nucl. Inst. Methods Phys. Res. B 2015, 361, 397-401. [CrossRef]

49. Chmeleff, J.; Blanckenburg, F.; Kossert, K.; Jakob, D. Determination of the ${ }^{10}$ Be half-life by multicollector ICP-MS and liquid scintillation counting. Nucl. Instr. Meth. Phys. Res. Sect. B Beam Interact. Mater. Atoms 2010, 268, 192-199. [CrossRef]

50. Korschinek, G.; Bergmaier, A.; Faestermann, T.; Gerstmann, U.C.; Knie, K.; Rugel, G.; Wallner, A.; Dillmann, I.; Dollinger, G.; Lierse Von Gostomski, C.; et al. A new value for the half-life of 10Be by heavy-ion elastic recoil detection and liquid scintillation counting. Nucl. Inst. Meth. Phys. Res. B 2010, 268, 187-191. [CrossRef]

51. Stone, J.O. Air pressure and cosmogenic isotope production. J. Geophys. Res. 2000, 105, 23753-23759. [CrossRef]

52. Balco, G.; Stone, J.O.; Lifton, N.A.; Dunai, T.J. A complete and easily accessible means of calculating surface exposure ages or erosion rates from ${ }^{10} \mathrm{Be}$ and ${ }^{26} \mathrm{Al}$ measurements. Quat. Geochronol. 2008, 3, 174-195. [CrossRef]

53. Dehnert, A.; Schlüchter, C. Sediment burial dating using terrestrial cosmogenic nuclides. Quat. Sci. J. 2008, 57, 210-225.

54. Sohbati, R. Luminescence, rock surfaces. In Encyclopedia of Scientific Dating Methods; Springer: Berlin, Germany, 2015; pp. 485-488.

55. Murray, A.; Marten, R.; Johnston, A.; Martin, P. Analysis for naturally occuring radionuclides at environmental concentrations by gamma spectrometry. J. Radioanal. Nucl. Chem. 1987, 115, 263-288. [CrossRef]

56. Murray, A.S.; Helsted, L.M.; Autzen, M.; Jain, M.; Buylaert, J.P. Measurement of natural radioactivity: Calibration and performance of a high-resolution gamma spectrometry facility. Radiat. Meas. 2018, 120, 215-220. [CrossRef]

57. Bøtter-Jensen, L.; Thomsen, K.J.; Jain, M. Review of optically stimulated luminescence (OSL) instrumental developments for retrospective dosimetry. Radiat. Meas. 2010, 45, 253-257. [CrossRef]

58. Guérin, G.; Mercier, N.; Adamiec, G. Dose-rate conversion factors: Update. Ancient TL 2011, 29, 5-8.

59. Aitken, M.J.; Mejdahl, V. Thermoluminescence Dating; Academic Press: London, UK, 1985; p. 359.

60. Prescott, J.R.; Hutton, J.T. Cosmic ray contributions to dose rates for luminescence and ESR dating: Large depths and long-term time variations. Radiat. Meas. 1994, 23, 497-500. [CrossRef]

61. Murray, A.S.; Wintle, A.G. Luminescence dating of quartz using an improved single-aliquot regenerative-dose protocol. Radiat. Meas. 2000, 32, 57-73. [CrossRef]

62. Wallinga, J.; Murray, A.; Wintle, A. The single-aliquot regenerative-dose (SAR) protocol applied to coarse-grain feldspar. Radiat. Meas. 2000, 32, 529-533. [CrossRef]

63. Rades, E.F.; Sohbati, R.; Lüthgens, C.; Jain, M.; Murray, A.S. First luminescence-depth profiles from boulders from moraine deposits: Insights into glaciation chronology and transport dynamics in Malta valley, Austria. Radiat. Meas. 2018, 120, 281-289. [CrossRef]

64. Sohbati, R.; Murray, A.; Buylaert, J.; Almeida, N.; Cunha, P.N.D. Optically stimulated luminescence (OSL) dating of quartzite cobbles from the Tapada do Montinho archaeological site (east-central Portugal). Boreas 2012, 41, 452-462. [CrossRef]

65. Freiesleben, T.; Sohbati, R.; Murray, A.; Jain, M.; Khasawneh, S.; Hvidt, S.; Jakobsen, B. Mathematical model quantifies multiple daylight exposure and burial events for rock surfaces using luminescence dating. Radiat. Meas. 2015, 81, 16-22. [CrossRef]

66. Bellin, N.; Vanacker, V.; Kubik, P.W. Denudation rates and tectonic geomorphology of the Spanish Betic Cordillera. Earth Plan. Sci. Lett. 2014, 390, 19-30. [CrossRef] 
67. Portenga, E.W.; Bierman, P. Understanding Earth's eroding surface with ${ }^{10}$ Be. GSA Today 2011, $21,8$. [CrossRef]

68. Jalut, G.; Montserrat Martí, J.; Fontugne, M.; Delibrias, G.; Vilaplana, J.M.; Julià, R. Glacial to interglacial vegetation changes in the northern and southern Pyrenees: Deglaciation, vegetation cover and chronology. Quat. Sci. Rev. 1992, 11, 449-480. [CrossRef]

69. Suc, J.-P.; Popescu, S.-M. Pollen Records and Climatic Cycles in the North Mediterranean Region Since 2.7 Ma; Geology Society: London, UK, 2005; pp. 147-158.

70. Gonzáles-Sampériz, P.; Aranbarri, J.; Pérez-Sanz, A.; Gil-Romera, G.; Moreno, A.; Leunda, M.; Gallejo, M.S.; Corella, J.P.; Morellon, M.; Oliva, B.; et al. Environmental and climate change in the southern Central Pyrenees since the last glacial maximum: A view from the lake records. Catena 2016, 149, 668-688. [CrossRef]

71. Pérez-Sanz, A.; González-Sampériz, P.; Moreno, A.; Garces, V.B.; Romera, G.G.; Rieradevall, M.; Tarrats, P.; Alvarez, L.L.; Morellon, M.; Belmonte, A.; et al. Holocene climate variability, vegetation dynamics and fire regime in the central Pyrenees: The Basa de la Mora sequence (NE Spain). Quat. Sci. Rev. 2013, 73, 149-169. [CrossRef]

72. Vannière, B.; Power, M.J.; Roberts, N.; Tinner, W.; Carrion, J.; Magny, M.; Bartlein, P.; Colombaroli, D.; Daniau, A.L.; Finsinger, W.; et al. Circum-Mediterranean fire activity and climate changes during the mid-Holocene environmental transition (8500-2500 cal. BP). Holocene 2011, 21, 53-73. [CrossRef]

73. Benito, G.; Macklin, M.G.; Panin, A.; Machado, M.J.; Fontana, A.; Jones, F.A.; Machado, M.J.; Matlakhova, E.; Mozzi, P.; Zielhofer, C. Recurring flood distribution patterns related to short-term Holocene climatic variability. Nat. Sci. Rep. 2015, 5, 16398. [CrossRef]

74. García-Ruiz, J.M.; Sanjuán, Y.; Gil-Romera, G.; Samperiz, G.P.; Begueria, S.; Arnaez, J.; Perez, C.A.; Villar, A.G.; Martinez, J.A.; Renault, L.N.; et al. Mid and late Holocene forest fires and deforestation in the subalpine belt of the Iberian range, northern Spain. J. Mount. Sci. 2016, 13, 1760-1772. [CrossRef]

75. Molliex, S.; Rabineau, M.; Leroux, E.; Bourlès, D.L.; Authemayou, C.; Aslanian, D.; Chavet, F.; Civet, F.; Jouët, G. Multi-approach quantification of denudation rates in the Gulf of Lion source-to-sink system (SE France). Earth Plan. Sci. Lett. 2016, 444, 101-115. [CrossRef] 